\title{
Malformation and death X Alcoholism: perspective of Nursing the Theory of Transitions for alcoholic pregnant women
}

\author{
Malformação e morte X Alcoolismo: perspectiva da Enfermagem com a Teoria da Transição em gestantes \\ Malformación y muerte X Alcoholismo: Perspectiva de Enfermería con la Teoría De La Transición en embarazada
}

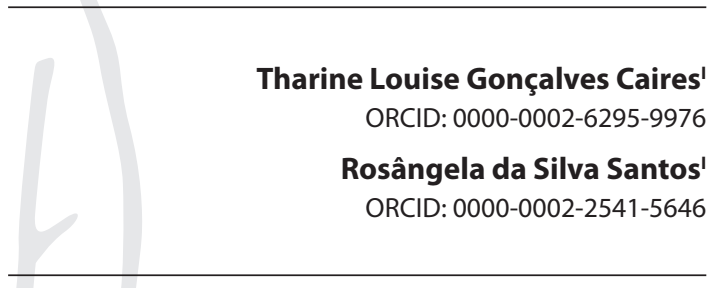

'Universidade do Estado do Rio de Janeiro. Rio de Janeiro, Rio de Janeiro, Brazil.

How to cite this article: Caires TLG, Santos RS. Malformation and death X Alcoholism: perspective of Nursing the Theory of Transitions for alcoholic pregnant women. Rev Bras Enferm. 2020;73(1):e20180233. doi: http://dx.doi.org/10.1590/0034-7167-2018-0233

Corresponding Author: Tharine Louise Gonçalves Caires E-mail: tharinecaires@yahoo.com.br

EDITOR IN CHIEF: Dulce Aparecida Barbosa ASSOCIATE EDITOR: Hugo Fernandes

Submission: $04-23-2018$

Approval: 08-26-2018

\begin{abstract}
Objective: To analyze the knowledge of women who are being treated in Psychosocial Care Centers for Alcohol and Drugs about the harm caused by alcohol consumption during pregnancy, especially regarding fetal malformation. Method: Qualitative, descriptive and exploratory study using the Life Narrative approach. Data was collected between February and May 2016, in the city of Rio de Janeiro, with an open interview with the guiding question: "Tell me about your life in relation to alcohol consumption during pregnancy and the guidance received in prenatal care". Results: The narratives revealed lack of information and fear of malformation (physical) and fetal death due to alcohol consumption during pregnancy. Discussion: Malformation or fetal death may trigger a transitional process in women. Final Considerations: Women have incipient knowledge about the effects of alcohol on the fetus. They consider that alcohol can only cause physical defects in the children.

Descriptors: Pregnant Women; Alcoholism; Nursing; Women's Health; Mental Health.
\end{abstract}

\section{RESUMO}

Objetivo: Analisar o conhecimento das mulheres, tratadas nos Centros de Atenção Psicossocial para álcool e drogas, acerca dos malefícios ocasionados pelo álcool na gestação, principalmente em relação à malformação fetal. Método: Pesquisa qualitativa, descritiva e exploratória. Utilizou o método Narrativa de Vida. Dados coletados entre fevereiro e maio de 2016, no município do Rio de Janeiro, com entrevista aberta e questão norteadora:"Fale-me a respeito de sua vida que tenha relação com uso de bebida alcoólica durante a gestação e as orientações recebidas no pré-natal". Resultados: As narrativas revelaram falta de informação e medo de malformação (física) e morte fetal relacionados ao uso do álcool por gestantes. Discussão: Malformação ou morte fetal podem desencadear um processo transicional nas mulheres. Considerações Finais: As mulheres têm incipiente conhecimento de que o álcool pode acarretar danos ao feto. Consideram que a bebida pode influenciar, somente, no aparecimento de defeitos físicos nos filhos.

Descritores: Gestantes; Alcoolismo; Enfermagem; Saúde da Mulher; Saúde Mental.

\section{RESUMEN}

Objetivo: Analizar el conocimiento que poseen las mujeres tratadas por alcohol y drogas en los Centros de Atención Sicosocial, sobre los perjuicios que éstos ocasionan en la gestación. Método: investigación cualitativa, descriptiva y exploratoria en la que se utilizó el método Narrativa de Vida, con datos recolectados entre febrero y mayo de 2016 en el municipio de Rio de Janeiro mediante entrevista abierta e interpelaciones orientadoras: "Hábleme al respecto del uso de bebida alcohólica durante la gestación y sobre las orientaciones recibidas en el prenatal". Resultados: falta de información y miedo de malformación (física) y muerte fetal. Discusión: La malformación y/o la muerte fetal pueden desencadenar un proceso transicional en las mujeres. Consideraciones Finales: Las mujeres tienen un conocimiento precario sobre los efectos del alcohol en el feto. Consideran que la bebida influencia más que nada en la aparición de defectos físicos en sus hijos.

Descriptores: Gestantes; Alcoholismo; Enfermería; Salud de la Mujer; Salud Mental. 


\section{INTRODUCTION}

It is believed that genetic predisposition to alcoholism is stronger for men than for women ${ }^{(1)}$. However, there has been a significant increase in the number of women who consume alcohol $^{(2)}$. The numbers indicate that alcohol consumption has increased more sharply among women than among men. Also, the onset-age of alcohol use has decreased among women ${ }^{(3)}$.

Women's alcohol consumption affects their mental health and is frequently associated with family problems, family violence and troubled relationships. In the family sphere, the negative repercussions of alcohol consumption are even more intense for women. They are marginalized and lose credibility, since alcohol abuse interferes with the performance of socially and culturally defined roles of women: to guide, educate and protect her children and family ${ }^{(4)}$.

The criticism is more severe when alcohol is used during pregnancy, mainly because alcohol consumption in this period increases the risk of mortality and the incidence of diseases in women's health. The direct effects on the fetus and on the newborn are also varied. The literature shows a higher risk of spontaneous abortion, cognitive deficit, non-hereditary congenital disorders and fetal malformations ${ }^{(2)}$.

According to the Theory of Transitions, one of the roles of the nursing professional is helping women to deal with possible fetal malformation ${ }^{(5)}$. Changes and differences are essential properties of transition which are similar, but not synonymous. They are essential in transition because every transition involves a change; however, not every change lead to a transition process. Women who consume alcohol during pregnancy can experience changes in their lives due to fetal malformation.

The diagnosis can be the event that initiates this process, and, to fully understand it, it is important to identify and describe the consequences and meanings of changes related to nature, temporality, perceived importance, social norms and expectations in the individual's life. Unmet or divergent expectations, different worldviews and feeling different or being seen as different may change the way a person lives and sees the world ${ }^{(5)}$.

Thus, nursing professionals have two important roles that are currently deficient: providing information about the effects of alcohol consumption on the fetus( ${ }^{(6)}$ and helping the woman in the transition from the loss of a "perfect" infant to having a baby with a malformation (in the case of those who receive this diagnosis).

One of the places these women can receive care is the Psychosocial Care Center for Alcohol and Drugs (CAPSad). This center - which is part of the Psychosocial Care Centers (CAPS), one of the main instruments of the Brazilian Psychiatric Reform - gave rise to a change in the care provided for alcohol dependent patients, which was previously offered mainly in psychiatric hospitals $s^{(7)}$.

However, adherence to treatment in these centers is still low among alcoholic women. Stigma such as prostitution and rebellion are often reproduced by a large part of the Brazilian population. This reality may be the determinant factor for the small numbers of alcoholic women being treated. In addition, women are more concerned about their self-image when exposing themselves to treatment in which they must see other people ${ }^{(8)}$.

Despite the low adherence, support groups have brought benefits to the physical and mental health of women attending CAPSad, especially to their self-esteem, reaffirming the importance of this type of care. It is worth emphasizing the importance of the nurse in the health care provided to alcoholic women, from health promotion to care measures, when the disease has already developed ${ }^{(9)}$.

Studies that address pregnant women in CAPSad are even more scarce. These centers should be prepared to welcome these women and offer the best kind of assistance according to their needs; after all, many women start this treatment pregnant or become pregnant during treatment.

\section{OBJECTIVE}

To analyze the knowledge of women who are being treated in CAPSad about the harm caused by alcohol consumption during pregnancy, especially regarding fetal malformation.

\section{METHOD}

The Narrative method was used, which results from a particular form of interview called "narrative interview". In this type of interview the researcher asks the interviewee to talk about their whole experience or part of $\mathrm{it}^{\left({ }^{(10)}\right.}$. In this study, the life narratives of alcoholic women about their gestation(s) were discussed.

\section{Ethical aspects}

The research was approved by the Research Ethics Committee (REC) of the Rio de Janeiro Municipal Department of Health and Civil Defense (SMSDC/RJ). It is in accordance with Resolution No. 466/2012 of the National Health Council and guarantees respect for human dignity and special protection for participants in scientific research involving human beings ${ }^{(11)}$.

The women participating in the study were given orientation on reading, understanding, and accepting the Informed Consent Term. They were also instructed on voluntary participation, guarantee of secrecy and anonymity when using their narratives. The participants were identified by the letter $E$ followed by the chronological order of the interview: E1, E2...

The life narrative approach was used with the objective of gaining deep knowledge about the subject. This method results from a particular form of interview called "narrative interview", in which the researcher asks the interviewee to talk about their whole experience or part of it ${ }^{(11)}$. In this study, the life narratives of alcoholic women about their gestation(s) were discussed.

\section{Theoretical framework}

The theory of transitions, which was used in this study, was developed in the 1960 s by a nurse, sociologist, researcher and theoretician. She defined transition as a passage or movement from one state, condition, or place to another. Changes in health status, role relationships, expectations or abilities involve changes in the needs of all the different systems of a person ${ }^{(12)}$.

Transition is considered a central concept in Nursing, given that nurse and client usually meet during periods of transition and instability, which are related to changes in the development and/or process of health or illness ${ }^{(12)}$. It envolves adaptation and integration to the new stage. The transition is more effective if 
the person knows, beforehand, what triggers this change, anticipates the event, prepares to adapt to this change and is aware of the possibility of facing multiple transitions at the same time ${ }^{(13)}$.

The meaning of the transition for the individual is a subjective perception, essential for understanding the process. This meaning can be positive, neutral or negative and results from a transition that is desired and planned or not. Expectations regarding the transition depend on previous experiences that may or may not interfere with this one ${ }^{(14)}$.

\section{Type of study}

This is a qualitative, descriptive and exploratory study based on the comprehension of issues involving women who consumed alcohol during pregnancy.

\section{Methodological procedures}

At first, it was established that the interviews would cease when they reached saturation point, that is, when the researcher realized that there was nothing new being added to the topic of study. After identifying this point, three more interviews would be conducted to confirm data saturation. Thus, it would be possible to comply with what is advocated in literature: when no new data emerges, the saturation point is reached, and the research is considered provisionally concluded ${ }^{(10)}$.

However, as previously mentioned, there is a low number of women adhering to this treatment, especially when involving alcohol consumption. In addition, not all of them are willing to talk about their lives and the abusive use of this substance, due to several different factors, especially shame and fear of stigma. This way, all the women who were being treated in the CAPSad (some of them often attended the centers, and others required an active search by the professionals) and who consumed alcohol during pregnancy were interviewed in the period from January to May 2016. A total of 17 women were interviewed.

\section{Study setting}

The study was conducted in four CAPSad in the city of Rio de Janeiro, out of a total of five. Only one CAPSad was not included in the study.

\section{Participants}

Participants were 17 women over 18 years old who consumed alcohol during pregnancy and were being treated at a CAPSad.

\section{Data collection and organization}

The instruments used for the collection of the narratives was composed of a header and questions related to their characterization: identification, civil status, level of education, family income, current age, age in which they started drinking, time of treatment in the CAPSad, alcohol abstinence (or not), number of pregnancies, abortions and children, type of delivery and prenatal (local and type of professional). There was also an open interview with the following guiding question: "Tell me about your life in relation to alcohol consumption during pregnancy and the guidelines received in prenatal care".
As recommended by the method, familiarization with the theme occurred before the collection of the narratives. A presentation on the research theme for all the professionals of these Centers was previously scheduled with the CAPSad directors and occurred in group meetings, as suggested by the directors themselves. This approach is considered important, as many professionals, despite working with alcoholic women, did not correlate alcohol use and abuse with possible harm to the fetus.

This familiarization provided an opportunity to be always present in the CAPSad, precisely with the intention of getting closer to the health professionals and, mainly, to the participants of the study. Although the first contact with these women happened at the time of the interview, it was not an obstacle for them to tell, naturally and in rich detail, their life stories.

As the method recommends, the researcher cannot interfere in the narrative of the participants. The role of the research is only to demonstrate, through corporal expression, that they are being listened to, demonstrating attentive listening. In addition, if it is related to the theme, the researcher may resume something already said by the participant and ask for further clarification, without, however, introducing new questions besides the first one.

The interviews were digitally recorded in a Musical Player 3 (MP3), after the consent of the participant. The participants were also informed of the possibility of withdrawing at any time, without risk to the continuity of their treatment and/or professional performance. The recorded material will be kept in the researcher's possession, in a digital file, for a period of five years, and then destroyed.

All interviews were transcribed in full right after their end, keeping the errors and vices of language. Soon after, the narratives were read to identify those that were similar. Thus, it was possible to identify the core meanings in the narratives. The analysis of the presence and frequency of these contents in a narrative consists of pre-analysis. In this phase, the narrative fragments are read as a group, aiming to exhaust the material, to understand the content and to correlate it with the theoretical framework ${ }^{(10)}$. These observations were marked in the narrative fragments by using the same color and then giving the same title. This stage, called coding, generated 18 core meaning.

The next step was recoding, which consisted of rereading and comparing the core meaning. The number of times these meanings appeared was counted to characterize their recurrence.

\section{Data analysis}

After retranscriptions, rereadings and recodifications, the narratives were grouped and summarized, originating the analytical categories that were analyzed comparatively and by thematic analysis. In this technique, the data are grouped by themes and examined by the researcher to make sure that all the manifestations have been included and compared ${ }^{(10)}$.

\section{RESULTS}

Among the 17 women interviewed, more than half (10) finished high school, some of them started higher education (02) and others even finished it (05). 
Eleven of them had a family income above $\mathrm{R} \$ 1000.00$. However, it was possible to observe that some of them survived with few resources, as was the case of $\mathrm{E} 3(\mathrm{R} \$ 156.00)$ and $\mathrm{E} 11(\mathrm{R} \$ 272.00)$. All of them were above 30 years old, and most were between 30 and 40 years old (09 participants). Seven of them were single, six were married, three were divorced and one was widowed.

Most of the women (12) started drinking alcohol when they were between 10 and 17 years old and, as all of them are over 30, it is evident that many have consumed alcohol for more than 10 years.

Alcohol abstinence is another important factor. Although all the interviewees were in treatment (at least for two months and at most for two years), many (10) were not abstinent.

Regarding the number of pregnancies, parity and abortions (spontaneous and/or induced), only one woman was pregnant only once, and the majority (12) reported abortions. There were no significant differences regarding the type of delivery: eight had vaginal deliveries and nine had c-sections. All of the women received prenatal care and only one of them attended to less than five visits.

Regarding the guiding question of the study, the narratives showed lack of information, mainly regarding the harm/damage that alcohol can cause to her and the child:

It's, you know, as they say... when you are 17, 18 years old you don't know the harm of what you're doing... don't know that drinking can affect you kid's health. So, as I drank little it did not affect my daughter [...]. (E6)

[...] he's very aggressive... [son] he's already set fire in the house... I was scared... because I didn't know how to deal with him... I didn't know if it was the booze that made him like that... nobody told me... but I don't think so... because it was just him out of six children, you know? (E11)

However, some of them had a notion (consciousness) that alcohol can be harmful to the baby, as demonstrated in the following narratives:

Because you know... he was born smaller... I think it's because of the alcohol, right? (E8)

Ah... I started cutting it down on my own, so I did not transfer alcohol to the child. Although I have higher education, we always expect the doctor to alert us, to give us details about what it can cause... but unfortunately at that time, even because I did not understand alcoholism as a disease, and the doctor couldn't have seen it too... So, I did not receive orientation based on how much I could be damaging that life. [...]. (E9)

Perhaps this slight awareness of the harms of drinking during pregnancy made some women fear a diagnosis of fetal malformation:

I could not stop drinking, and I was afraid she would be born defective. (E3)

And that was why I felt bad about myself... that's what I was afraid of... because if he had a health problem, a heart condition, if he wasn't normal, if he didn't have an arm or a leg, or something [...]. (E13)
Thanks God my children have no malformation [...] I was very afraid of that... (E14)

It is worth noting that this diagnosis of fetal malformation is strictly related to a physical defect, and they do not consider, for example, the possibility of a neurocognitive disorder:

My children are a little slow in school... they have difficulty learning; they get held back in school... I have to be very demanding with them... to pay attention to their teacher [...], kid stuff, you know? (E14)

In addition to malformation, fear of fetal death was also present in the narratives of the women interviewed:

When I drank, I did not feel her move, and then I thought: Oh my God! Am I killing my daughter?? (E1)

Some days my son would not move, so I thought he was dead inside my belly. (E4)

[...] I stopped drinking a week before she was born, it was when I thought she had died in my belly, I was desperate because she did not move anymore... (E10)

\section{DISCUSSION}

The analysis of the narratives allows us to infer that fetal malformation and the imminence of fetal death are situations that can trigger a transitional process in women. Transitions often involve various emotions, of which many are related to the difficulties encountered during the transition process ${ }^{(5)}$.

One of the emotions felt by the women in this study was fear of a diagnosis of malformation or fetal death. This feeling may be related to lack of knowledge about the harms of alcohol use for her and, especially, for the child in her womb.

The fear of the consequences of alcohol consumption to the fetus was analyzed from the perspective of the Theory of Transitions ${ }^{(5)}$. Transition is defined as the passage from one state, condition or place to another and is related to a change in health status, expectations or abilities. This denotes changes in needs of all human systems, since humans are in constant interaction with the environment and have the capacity to adapt to its transformations. But, a disease or the risk of disease makes a person experience or be on the verge or experience an imbalance ${ }^{(15)}$.

The birth of a child with some malformation is also a moment of preparation for the mourning of a normal child who did not come. In these cases, women may experience crying, shame, blame for believing they were the cause of this harm, and fear of prejudice or discrimination from others ${ }^{(16)}$. Thus, even if it is involuntary and unconscious, the pregnant woman prepares for the deconstruction of a healthy child to receiving a baby with a malformation.

Every transition cause changes; however, not every change leads to a transition process ${ }^{(5)}$. This way, women, when facing a fear of the unknown, a fear of how their child will be born, report a transition that they faced within themselves, a doubt that they had during the whole gestation and that only disintegrated in the moment of childbirth: is there or is there not fetal malformation caused by alcohol consumption?

The women in this study were afraid that alcohol might cause some harm or malformation to their child, although they did not 
know what kind of harm that could be. Among the malformations considered non-hereditary, children may present craniofacial anomalies (small palpebral fissure, palpebral ptosis, hemifacial atrophy, upturned nose; nose, thin upper lip, smooth philtrum), malformations of the CNS (microcephaly and structural abnormalities of the brain such as agenesis of the corpus callosum and cerebellar hypoplasia) and congenital anomalies (cardiac malformation, skeletal and limb malformations, renal abnormalities, absence/ abnormality of the auricle, vision problems, cleft lip or palate) ${ }^{(17)}$.

In addition to these characteristics, the child may present a group of conditions called fetal alcohol syndrome (FAS), or the incomplete condition, known as fetal alcohol spectrum disorders (FASD). SAF is diagnosed, mainly, by a triad of characteristics: deficiencies in pre and postnatal development; facial dysmorphism (palpebral fissure, thin upper lip and flat face) and dysfunction in the Central Nervous System (intellectual deficiency and/or attention deficit) $)^{(18)}$.

Technological advances in fetal medicine, such as the fetal ultrasound, have made screening and diagnosis of congenital anomalies more efficient. Therefore, contact with this reality has also been occurring sooner ${ }^{(19)}$.

The effects of alcohol consumption on the fetus are complex and varied, making clinical suspicion and diagnosis more difficult due to the variety of clinical and behavioral aspects associated with this reality ${ }^{(17)}$.

Thus, it can be said that the diagnosis of fetal malformation causes intense suffering and distress. These feelings can be articulated in a faster or slower manner, according to personality traits related to loss and mourning, and also according to the stage in which the woman receives the news of the fetal malformation ${ }^{(19)}$. According to the Theory of Transitions, adaptation and integration to the new stage will be more successful if the person knows, beforehand, what triggers this change, anticipates the event, prepares to adapt to this change and is aware of the possibility of facing multiple transitions at the same time ${ }^{(5)}$.

Thus, the transition to the new situation will depend on factors such as severity, marital relationship, familial structure, and health care received. Therefore, the emotional reaction to the diagnosis is completely personal and the woman can present a rational reaction and appear calm and accepting or a reaction of complete lack of control ${ }^{(5)}$.

Each woman will use the defense mechanisms available at that moment. Sometimes, she can even try to find guilt, generating conflict $^{(19)}$. The transition from one stage to another can be positive, neutral or negative, and results from a process that is desired and planned or not. Expectations regarding the transition depend on previous experiences that may or may not interfere with this one.

Upon receiving a diagnosis of fetal malformation, the woman can experience a process of crisis, which will be lived in a very particular way. The nurse needs to understand that the disease does not represent only a physical change, but is also an opportunity to start living in a conscious and deliberate way, modifying the rhythm and direction of the person's individual life experience ${ }^{(20)}$.

Pregnancy is described as a period of crisis experienced by woman deliberately or not. However, no one wants or expects a child with a malformation. As much as people show acceptance for what is different and society encourages people to adopt a culture of inclusion, the difficulties brought about by this type of condition are added to the covert prejudice that still does exist ${ }^{(21)}$.

This situation may be aggravated when the malformation is apparent (such as a craniofacial malformation), that is, it is so evident that there is no doubt in accepting the limitation - even if temporary, since certain cases can be corrected or minimized with surgery.

Prenatal diagnosis of malformation incompatible with life can cause intense suffering and a series of implications for the pregnant woman, such as: frustration, guilt, inability to cope with loss, family crisis and social isolation ${ }^{(22)}$. Fetal malformation is an example of a change in which the woman and her family need adjustment and adaptation.

There is a potential for maladjustment when experiencing new knowledge, and nursing professionals can help adjusting or adapting to the new situation or circumstance. In this sense, nursing actions must be based on the individual, understanding the transition from the perspective of those who experience it. The wide variety of events that trigger this transition process, such as parenting relationships (motherhood and paternity) and the birth of a child, must be considered ${ }^{(6)}$.

\section{Study limitation}

The limitation of this study was not collecting data in all CAPSad.

\section{Contributions to the area of nursing}

This study contributes to nursing care and to the production of knowledge, given the low number of published studies that address alcoholic pregnant women. In addition, it contributed with knowledge about the performance of health professionals in Primary Care, especially nurse, in the care of pregnant women with a focus on the prevention of alcohol consumption during pregnancy.

\section{FINAL CONSIDERATIONS}

The analysis of the narratives showed that most women have knowledge, even if is incipient, about the possible effects of alcohol consumption for the fetus; however, they do not know exactly what these damages are. Many of them believe that drinking can lead to the appearance of malformations (only physical defects) in the children.

The analysis of this theme based on the theoretical framework of the theory of transitions enabled a direct approach to the involvement of pregnant women with alcohol and provided reflections for nursing professional performance. It was also possible to perceive the importance of contemplating aspects of the client's social context, favoring a comprehensive care and supporting coping and healthy transitions.

The originality of the study lies in the use of the Theory of Transitions as theoretical framework to analyze alcohol consumption during pregnancy. It is worth noting, however, that the data presented do not cover the totality of the problem of alcohol use and abuse during pregnancy, but already represent advances.

The Life Narrative of these 17 women who experienced the repercussions of alcohol consumption revealed important aspects that should be considered at local and regional administration. Thus, this study can certainly support nursing training and practice 
regarding assistance to pregnant women, especially in the CAPSad, since they do not seem to discuss the relationship between alcohol and pregnancy in this place, where they focus only on alcoholism.

\section{FUNDING}

Researcher funded by CNPq (PhD scholarship).

\section{REFERENCES}

1. Mangueira SO, Lopes MVO. Família disfuncional no contexto do alcoolismo: análise de conceito. Rev Bras Enferm. 2014;67(1):149-54. doi: 10.5935/0034-7167.20140020

2. Zanoti-Jeronymo DV, Nicolau JF, Botti ML, Soares LG. Repercussões do consumo de álcool na gestação: estudo dos efeitos no feto. Braz J Surg Clin Res [Internet]. 2014 [cited 2017 Jun 23];6(3):40-6. Available from: https://www.mastereditora.com.br/periodico/20140501_181135.pdf

3. Zilberman ML, Tavares H, Blume SB, El-Guebaly N. Substance use disorders: sex differences and psychiatric comorbidites. Can J Psychiatry. 2003;48(1):5-13. doi: 10.1177/070674370304800103

4. Silva NA, Oliveira JL, Souza J. Alcohol and tobacco consumption among seamstresses from the city of Formiga - Minas Gerais. SMAD, Rev. Eletrônica Saúde Mental Álcool Drog. 2016;12(4):222-30. doi: 10.11606/issn.1806-6976.v12i4p222-230

5. Meleis Al. Theoretical nursing; development \& progress. 5th ed. Philadelphia: Lippincott; 2011.

6. Meleis Al, Sawyer LM, Im EO, Messias DKH, Schumacher K. Experiencing Transitions: An Emerging Middle-Range Theory. In.: Transitions theory: middle-range and situation-specific theories in nursing research and practice. New York: Spring Publishing Company; 2010. p. 52-64.

7. Lima LPM, Santos AAP, Povoas FTX, Silva FCL. O papel do enfermeiro durante a consulta de pré-natal à gestante usuária de drogas. Rev Espaço Saúde [Internet]. 2015 [cited 2017 Mar 06];16(3):39-46. Available from: http://espacoparasaude.fpp.edu.br/index.php/espacosaude/ article/viewFile/394/382

8. Ministério da Saúde (BR). Secretaria Executiva. Coordenação Nacional de DST/Aids. A Política do Ministério da Saúde para atenção integral a usuários de álcool e outras drogas [Internet]. Brasília: Ministério da Saúde; 2003 [cited 2017 Mar 06]. Available from: http://bvsms.saude.gov. br/bvs/publicacoes/politica_atencao_alcool_drogas.pdf

9. Marangoni SR, Gavioli A, Beraldo BR, Oliveira MLF. Perfil sociodemográfico das mulheres usuárias de álcool e outras drogas na gravidez. Rev Uningá [Internet]. 2018 [cited 2018 Mar 26];30(3):19-24. Available from: http://revista.uninga.br/index.php/uningareviews/article/view/2034

10. Veloso LUP, Monteiro CFS. Prevalence and factors associated with alcohol use among pregnant adolescents. Rev Latino-Am Enfermagem. 2013;21(1):433-41. doi: 10.1590/S0104-11692013000100020

11. Bertaux D. Narrativas de vida: a pesquisa e seus métodos. Natal: EDUFRN; São Paulo: Paulus; 2010.

12. Ministério da Saúde (BR). Conselho Nacional de Saúde (CNS). Resolução n 466, de 12 de dezembro de 2012. Aprova normas regulamentadoras de pesquisas envolvendo seres humanos. Brasília: Ministério da Saúde; 2012 [cited 2018 Feb 12]. Available from: http:// bvsms.saude.gov.br/bvs/saudelegis/cns/2013/res0466_12_12_2012.html

13. Meleis Al, Sawyer LM, Messias DKH, Schumacher K. Experiencing transitions: an emerging middle-range theory. ANS Adv Nurs Sci. 2000;23(1):12-28.

14. Chick N, Meleis Al. Transitions: a nursing concern. Pennsylvania: School of Nursing Department Papers, University of Pennsylvania; 1986.

15. Schumacher KL, Meleis Al. Transitions: a central concept in nursing. In: Transitions theory: middle-range and situation-specific theories in nursing research and practice. New York: Springer Publishing Company; 2010. p. 38-51.

16. Meleis Al. Theoretical nursing: development \& progress. 3rd ed. London: Lippincott; 2005.

17. Rocha PC, Britto e Alves MTSS, Chagas DC, Silva AAM, Batista RFL, Silva RA. Prevalência e fatores associados ao uso de drogas ilícitas em gestantes da coorte BRISA. Cad Saúde Pública. 2016;32(1):e00192714. doi: 10.1590/0102-311X00192714

18. Rodrigues LPS. Efeitos no feto da ingestão de álcool durante a gravidez [dissertação] [Internet]. Porto: Universidade Fernando Pessoa; 2014 [cited 2018 Feb 12]. Available from: https://bdigital.ufp.pt/bitstream/10284/4859/1/PPG_26299.pdf

19. Santos RS, Estefanio MP, Figueiredo RM. Prevention of fetal alcohol syndrome: input to obstetrical nurses' practice. Rev Enferm UERJ. 2017;25(1):277-93. doi: 10.12957/reuerj.2017.27793

20. Nunes TS, Abrahão AR. Maternal repercussions of fetal anomaly pre-natal diagnosis. Acta Paul Enferm. 2016;29(5):565-72. doi: 10.1590/1982-0194201600078

21. Reis LV, Araujo Júnior E, Guazzell CAF, Cernach MCSP, Torloni MR, Moron AF. Anomalias congênitas identificadas ao nascimento em recém-nascidos de mulheres adolescentes. Acta Med Port [Internet]. 2015 [cited 2017 May 15];28(6):708-14. Available from: https://www. actamedicaportuguesa.com/revista/index.php/amp/article/viewFile/6046/4549

22. Santos MM, Böing E, Oliveira ZAC, Crepaldi MA. Diagnóstico pré-natal de malformação incompatível com a vida: implicações psicológicas e possibilidades de intervenção. Rev Psicol Saúde [Internet]. 2014 [cited 2017 Apr 26];6(1):64-73. Available from: http://pepsic.bvsalud.org/ scielo.php?script=sci_arttext\&pid=S2177-093X2014000100009 